\title{
PENDAMPINGAN KEGIATAN BELAJAR DI RUMAH SECARA PRIVAT DI MASA PANDEMI COVID-19 DILINGKUNGAN KABUPATEN BANGLI BAGIAN UTARA
}

\author{
Putu Beny Pradnyana ${ }^{1)}$, I Nyoman Sudirman²), Desak Putu Anom Janawati ${ }^{3)}$ \\ 1)Program Studi Pendidikan Guru Sekolah Dasar, STKIP Suar Bangli, Bali, Indonesia \\ 2) Program Studi Bahasa dan Sastra Indonesia, STKIP Suar Bangli, Bali, Indonesia \\ ${ }^{3)}$ Program Studi Pendidikan Guru Sekolah Dasar, STKIP Suar Bangli, Bali, Indonesia \\ Corresponding author : Putu Beny Pradnyana \\ E-mail : putubenypradnyana380@gmail.com
}

\section{Diterima 12 November 2020, Direvisi 14 November 2020, Disetujui 15 November 2020}

\begin{abstract}
ABSTRAK
Tujuan pengabdian masyarakat ini adalah (1) untuk mengatasi masalah dan membantu masyarakat khusunya anak-anak usia sekolah dasar yang mendapatkan hambatan pada kegiatan pembelajaran di rumah, mengingat pembelajaran yang dilakukan secara daring di lingkungan Kabupaten Bangli bagian Utara yang merupakan kawasan wilayan Kota Bangli yang terpencil, (2) Membantu siswa kelas rendah tidak punya bahan pembelajaran di rumah, (3) membantu meminjamkan fasilitas dan media pembelajaran di rumah, dan (4) membantu meringankan beban orang tua dalam mengajarkan anakanak meraka di rumah. Kegiatan ini dilakukan dalam beberapa tahap, yaitu (1) Identifikasi masalah (2) analisis kebutuhan; (3) merancang pembinaan dan pendampingan; (4) melaksanakan pembimbingan; (5) monitoring dan Observasi hasil kegiatan; (6) pelaporan dan tindaklanjut. Hasil pengabdian ini adalah terbantunya pembelajaran daring di rumah selama masa pandemic Covid-19, orang tua siswa sudah bisa menggunakan gadget untuk pembelajaran daring anak mereka, bagi siswa kelas rendah sudah dibantu dalam menyediakan bahan ajar, meminjamkan fasilitas dan media pembelajaran dan para orang tua sangat merasa terbantukan dengan kegiatan pendampingan ini di masa pandemic Covid-19 dan dalam belajar di rumah selama masa pandemic Covid-19 dengan tetap memperhatikan protokol kesehatan.
\end{abstract}

Kata kunci: sekolah dasar; pembelajaran di rumah; pandemik covid-19.

\begin{abstract}
The objectives of this community service are (1) to solve problems and help the community, especially elementary school-age children who face obstacles to learning activities at home, given that learning is carried out online in the northern part of Bangli Regency which is a remote area of Bangli City. , (2) Helping low-grade students who do not have learning materials at home, (3) helping to lend facilities and learning media at home, and (4) helping to ease the burden on parents in teaching their children at home. This activity is carried out in several stages, namely (1) problem identification (2) needs analysis; (3) designing guidance and assistance; (4) carry out guidance; (5) observation of activity results; (6) reporting and follow-up. The result of this service is the help of online learning at home during the Covid19 pandemic, parents of students can use gadgets for their children's online learning, low-grade students have been assisted in providing teaching materials, lending facilities and learning media and parents are very felt helped by this assistance activity during the Covid-19 pandemic and in studying at home during the Covid-19 pandemic by still paying attention to health protocols.
\end{abstract}

Keywords: elementary school; home learning; covid-19 pandemic.

\section{PENDAHULUAN}

Kabupaten Bangli merupakan salah satu kabupaten yang ada di Provinsi Bali serta satu-satunya kabupaten di Bali yang tidak memiliki wilayah laut (terkurung daratan). Kota Bangli terletak di antaranya sebelah utara terdapat kabupaten Buleleng, di sebelah timur kabupaten Klungkung dan Karangasem, dan di sebelah baratnya adalah kabupaten Gianyar dan di sebelah seletan kabupaten Badung. Luas Wilayah Kabupten Bangli $520,81 \mathrm{~km}^{2}$.
Kota Bangli bagian utara terdiri dari Desa Abang, Songan, Abuan, Awan, Bantang, Banua, Batudinding, Batukaang, Batur Selatan, Batur Tengah, Batur Utara, Bayung cerik, Bayung Gede, Belancan, Belandingan, Belanga, Belantih, Binyan, Bonyoh, Buahan, Bunutin, Catur, Daup, Dausa, Gunung bau, Katung, Kedisan, Kintamani, Kutuh, Langgahan, Lembean, Mangguh, Manikliyu, Mengani, Pengejaran, Pinggan, Satra, Sekaan, Sekardadi, Selulung, Serai, Siakin, Songan A, 
Songan B, Subaya, Sukawana, Suter, Terunyan dan Ulian.

Beredarnya berita mengenai penyebaran virus Covid-19 sangat cepat terutamanya wilayah Bangli yang berada pada zona merah dalam penyebaran Covid-19 ini. Seperti yang peneliti kutip dari halam bahwa WHO tentang Coronavirus disease (COVID-19) is an infectious disease caused by a newly discovered coronavirus, virus corona (Covid19) merupakan penyakit menular yang baru saja ditemukan (WHO, 2020).

Jika dilihat pada tahun 2019, dunia digemparkan oleh virus Covid-19 yang menyerang pernapasan manusia dan dapat menyebabkan kematian. Virus yang dinamakan Novel Coronavirus atau COVID-19, virus ini berkembang dengan sangat pesat pertama kali ditemukan di Wuhan Negara Tirai Bambu, virus ini merupakan satu keluarga dengan virus penyebab SARS dan MERS, data statistik menyebutkan penyebaran Virus Covid-19 ini menyebar sangat cepat ke berbagai negara dunia, seperti Negara Indonesia sendiri, kasus virus Covid-19 pertama kalinya diumumkan dua pasien positif virus corona pada tanggal 2 Maret 2020 oleh Presiden Joko Widodo. Dua pasien itu adalah ibu dan anak yang diduga tertular dari warga negara Jepang. Selanjutnya 6 Maret 2020, Indonesia mengumumkan dua pasien positif virus corona sehingga jumlahnya menjadi Empat pasien, dan terus meningkat hingga pada tanggal 24 Mei 2020 terdapat 22.271 Kasus positif Covid-19 dan untuk wilayah Provinsi Bali terkonfirmasi 394 pasien Covid-19 (Kompas.com, 2020).

Melihat kasus covid-19 sudah melanda Negara Indonesia, maka secara nasional pembelajaran siswa di sekolah-sekolah dilakukan secara daring di rumah masingmasing, sesuai Surat Edaran Menteri Pendidikan dan Kebudayaan Nomor 4 Tahun 2020 tentang Pelaksanaan Pendidikan dalam Masa Darurat Covid-19, berdasarkan surat edaran ini maka siswa sudah harus belajar di rumah masing-masing. Belajar menurut Trianto (2010:9) adalah suatu proses yang ditandai dengan adanya perubahan pada diri seseorang. Belajar secara mandiri di di rumah bukanlah sesuatu yang biasa, mengingat kegiatan tersebut mulai dari penanaman dasar hingga pemahaman sampai siswa tersebut benarbenar memahami, terlebih lagi dilakukan secara daring.

Pelaksanaan pembelajaran daring yang telah dilakukan selama masa pandemik covid-19 ini belum begitu optimal, dikarenakan Pertama anak-anak usia sekolah dasar yang mendapatkan hambatan pada kegiatan pembelajaran di rumah, mengingat pembelajaran yang dilakukan secara daring di lingkungan Kabupaten Bangli Utara yang merupakan kawasan wilayan Kota Bangli yang terpencil. Kedua, siswa kelas rendah tidak punya bahan pembelajaran di rumah. Ketiga, kurang tersedianya fasilitas dan media pembelajaran di rumah. Keempat, terbatasnya orang tua siswa dalam mengajar anak-anak meraka di rumah dan yang Kelima, jarang mendapatkan pendampingan belajar di rumah selama masa pandemic Covid-19 dari sekolah. Selain itu, kegiatan pendampingan ini juga memberikan bantuan kepada orang tua siswa, khususnya dalam hal mengajarkan anak-anak mereka ditengah kesulitan para orang tua yang tidak memiliki gadget dan mendapingin orang tua siswa dalam menggunakan aplikasi pada gadget untuk belajar di rumah

Berdasarkan hasil observasi di beberapa wilayah ditemukan bahwa:

1. Banyak anak-anak usia sekolah dasar yang mendapatkan hambatan pada kegiatan pembelajaran di rumah,

2. Siswa kelas rendah tidak punya bahan pembelajaran di rumah,

3. Kurang tersedianya fasilitas dan media pembelajaran di rumah,

4. Terbatasnya orang tua siswa dalam mengajar anak-anak meraka di rumah dan Jarang mendapatkan pendampingan belajar di rumah selama masa pandemic Covid-19 dari sekolah.

5. para orang tua ada yang tidak memiliki gadget yang support terhadap pembelajaran daring.

6. Banyak dari masyarakat yang belum paham dalam menggunakan aplikasi pada gadget untuk belajar di rumah

Berdasarkan permasalahan tersebut, solusi yang tepat ditawarkan adalah pendampinga kegiatan belajar di rumah selama Pandemi Covid-19 pada Anak-Anak usia sekolah dasar di lingkungan Kabupaten Bangli Utara. Adapun solusi tersebut dapat diparkan seperti berikut.

1. Memberikan pendampingan belajar di rumah secara khusus dengan memperhatikan protokol kesehatan.

2. Membantu menyiapkan bahan pembelajaran untuk mempermudah siswa belajar durumah baik dengan akses internet maupun mengakses perpustakaan nasional (aplikasi "IPUSNAS”).

3. Membantu dalam hal peminjaman sarana pembelajaran di rumah, baik itu gadget atau yang lainnya, akses video melalui youtube memungkinkan dilakukan sebagai media audio visual. 
4. Memberikan pendampingan kepada orang tua siswa dalam mengajar anak-anak meraka di rumah dan

5. Memberikan pendampingan kepada orang tua siswa yang belum belum paham dalam menggunakan aplikasi pada gadget untuk belajar di rumah.

\section{METODE}

Pengabdian masyarakat ini dilaksaksanakan di Kabupaten Bangli bagian Utara, dengan mengambil tempat di Desa Songan, Desa Batur, Desa Kintamani, dan Desa Suter. Sebanyak 28 kepala keluarga sebagai mitra pengabdian ini.

Metode pelaksanaan pengabdian ini menggunakan Metode Pals yang dapat dijabarkan sebagai berikut. (1) Identifikasi masalah tentang permasalahan siswa belajar di rumah di masa pandemi Covid-19; (2) melakukan analisis kebutuhan untuk mengatasi permasalahan yang terjadi saat pembelajaran di rumah selama pandemi Covid-19; (3) merancang pembinaan dan pendampingan kepada siswa dan orang tua siswa; (4) melaksanakan pembimbingan terstruktur dan pembuatan bahan ajar yang disesuai dengan kelas dan materi pelajaran yang mereka tempuh saat itu; (5) monitoring dan Observasi kegiatan; (6) laporan dan tindaklanjut keberhasilan program.

Metode pelaksanaan pengabdian masyarakat pendampingan kegiatan belajar di rumah secara privat di masa pandemi covid-19 dilingkungan kabupaten bangli utara digambarkan sebagai berikut.

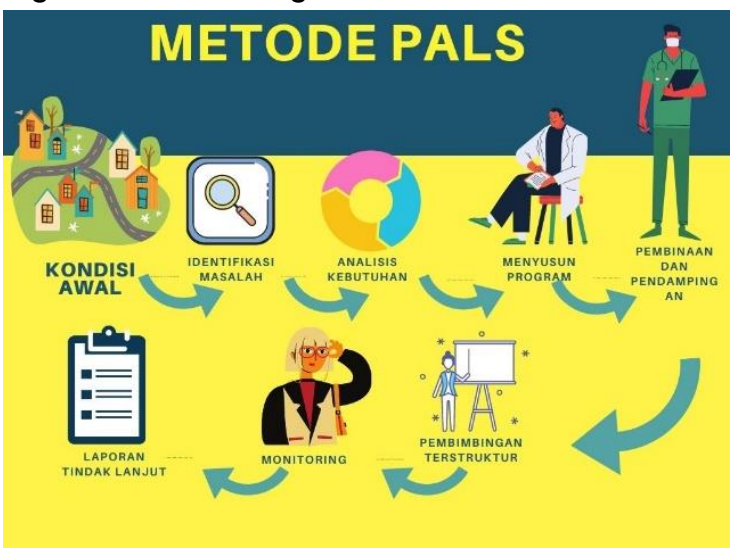

Gambar 1. Bagan Metode Pelaksanaan

Pada tahap pelaksanaan program dilakukan (1) koordinasi dan pembekalan tim kerja pelaksana program sesuai peruntukan mengatasi masalah pengabdian.

Melaksanakan penyusunan rencana program strategis sesuai dengan metode participatory action learning system (PALS). (3) Perancangan Program pendampingan kegiatan belajar di rumah secara privat di masa pandemi covid-19 dilingkungan kabupaten bangli utara, (4) Pelaksanaan aktivitas-aktivitas inisiasi program pengabdian, meliputi (a) pembinaan, (b) pendampingan, (c), pembimbingan terstruktur pada orang tua siswa dan siswa.

\section{HASIL DAN PEMBAHASAN}

Sebelum kegiatan ini dilaksanakan dengan terjun ke masyarakat, TIM pelaksana sudah dipastikan dengan secara ketat melaksanakan protokol kesehatan, diantaranya menggunakan masker, mencuci tangan atau menggunakan hands sanitaizer dan sebisa mungkin menjaga jarak.

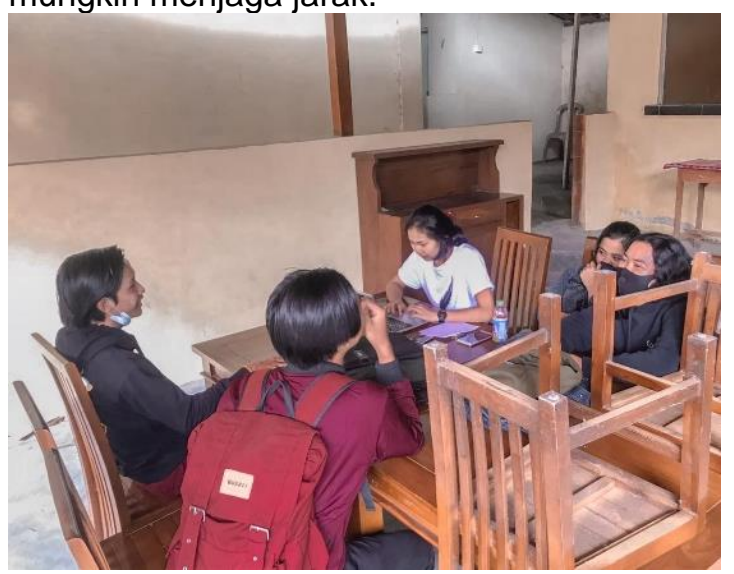

Gambar 2. Koordinasi Pembekalan TIM Pelaksana Program Pengabdian Kepada Masyarakat Di Lingkungan Kabupaten Bangli.

Pendampingan kegiatan belajar di rumah pada masa pandemi covid-19 pada anak-anak usia sekolah dasar di lingkungan Kabupaten Bangli bagian utara dilaksanakan seminggu 2 kali yakni hari Senin dan Kamis. Selain yang sudah terjadwalkan tersebut, kegiatan juga ada yang bersifat insidental, berdsarkan permasalahan yang dialami tiaptiap siswa.

Seperti misalnya banyak Banyak anakanak usia sekolah dasar yang mendapatkan hambatan pada kegiatan pembelajaran di rumah, mengingat pembelajaran yang dilakukan secara daring di lingkungan Kabupaten Bangli yang terpencil. Untuk mengatasi hal ini, perlu dilakukan pendampingan yang sifatnya insidental, hal ini dikarenakan banyak orang tua siswa maupun siswa itu sendiri belum paham terhadap penggunaan dan pelaksanan pembelajaran daring. Contoh kecil yang dapat penulis sampaikan adalah, penggunaan aplikasi whatsapp. Baik dalam hal melihat berkas dalam format PDF yang mengharuskan orang tua dan siswa tersebut mendownload aplikasi pendamping yang dapat digunakan untuk membaca file dengan format PDF. Begitu juga 
pada saat mereka mengirimkan foto atau vidio ke pada guru mereka sebagai bukti bahwa mereka sudah melaksanakan dan mengerjakan tugas yang diberikan oleh guru mereka.

Setiap hari senin dan kamis tim pengabdian masyarakat terjun memberikan pendampingan secara privat, untuk mengajarkan anak-anak belajar di rumah. Pendampingan secara privat ini dipilih untuk menghindari terjadinya kerumunan. Kegiatan pendampingan ini dibatasi dengan jumlah siswa yang ada di rumah yang bersangukat maksimal 4 orang siswa dengan berbagai jejang pendidikan di sekolah dasar dan tetap menerapkan protokol kesehatan untuk mencegah penyebaran virus Covid-19.

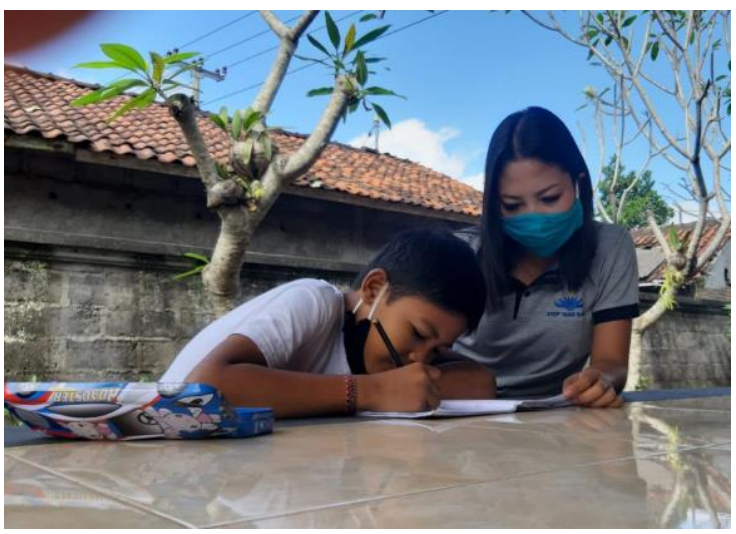

Gambar 3. Pendampingan Belajar di rumah Secara Privat di Desa Batur

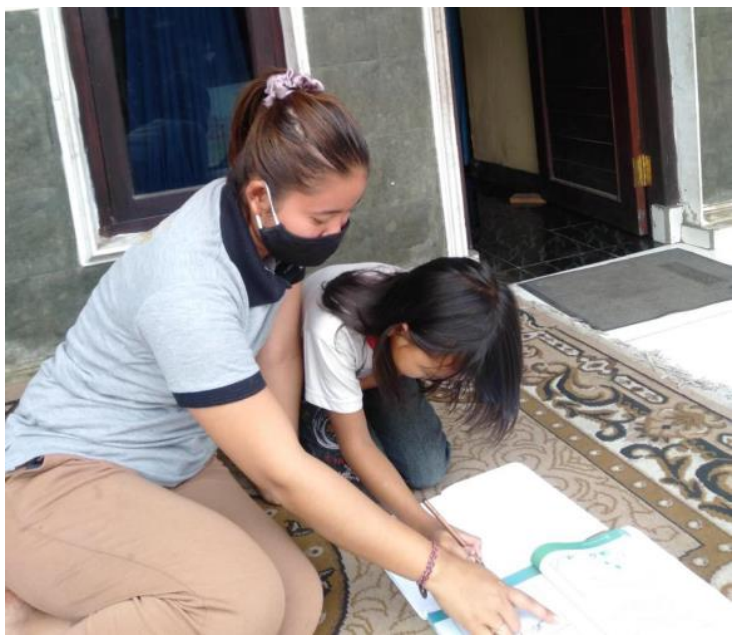

Gambar 4. Pendampingan Belajar di rumah Secara Privat di Desa Suter

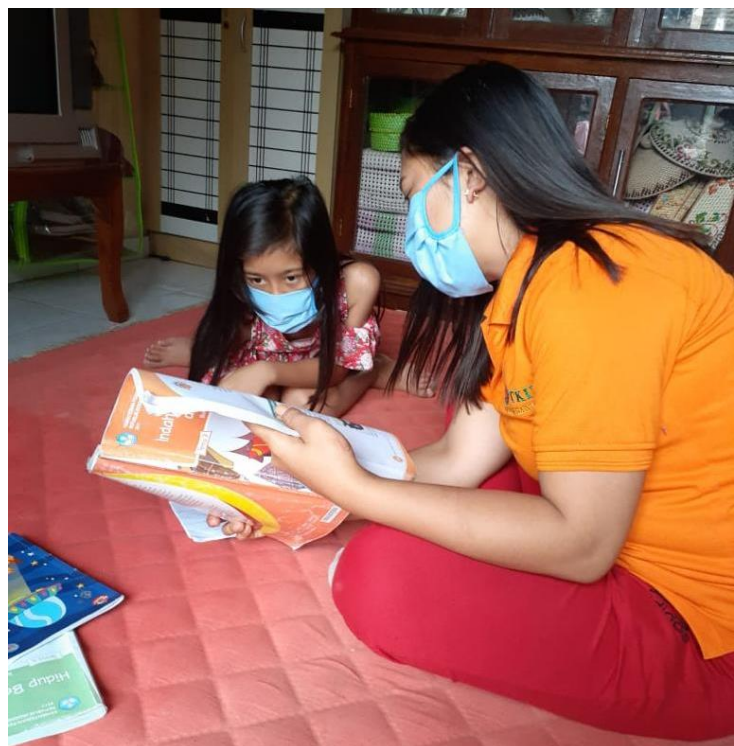

Gambar 5. Pendampingan Belajar di rumah Secara Privat di Desa Batur

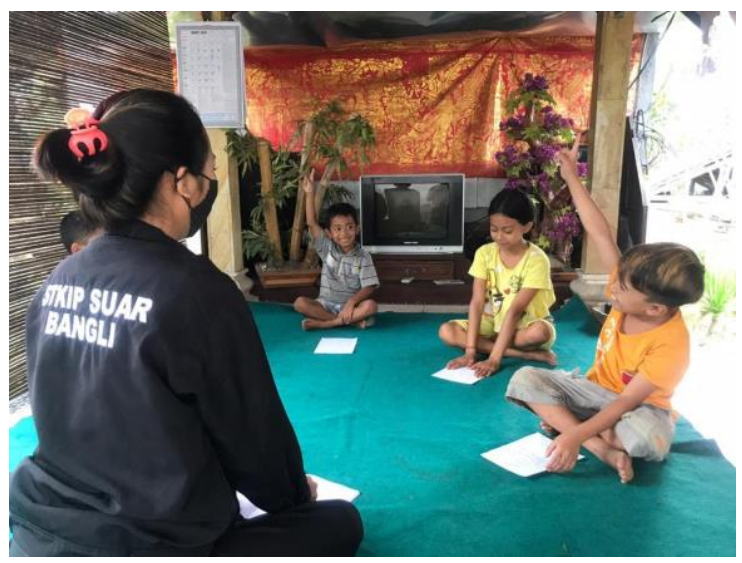

Gambar 6. Pendampingan Privat Maksimal 4 Orang Siswa di Desa Songan

Privat menurut kamus besar bahasa Indonesia adalah tersendiri. Jadi pola pembelajaan yang dilakuan secara tersendiri baik lingkungan rumah tersendiri maupun perorangan. Ada bebarapa alasan pada pelaksanaan pendampingan pendampingan kegiatan belajar di rumah masa pandemi covid19 dilingkungan kabupaten bangli bagian utara dilakukan secara privat.

Pertama, melihat situasi terkini sedang terjadi wabah penyakit Covid-19, sehingga perlu adanya keterbatasan dalam berkumpul. Pendampingan secara privat dipilih untuk meminimalisir penyebaran covid-19 namun siswa masih tetap mendapatkan pendampingan. Pendampingan ini sebelumnya telah melakukan observasi wilayah terhadap wilayahwilayah yang terdampak covid-19, apabila wilayah tersebut tidak ada yang terpapar covid19, maka TIM terjun kelokasi tersebut. Lokasi 
yang dipilih tidak jauh dari tempat tinggal TIM pengabdian ini.

Kedua, pendampingan secara privat ini dilakukan untuk menjalin komunikasi belajar yang lebih inten dan terfokus kepada maksimal sesuai dengan kesepakatan TIM pengabdian sebanyak 4 orang anak di satu tempat/rumah penduduk, pendampingan sebanyak 4 orang anak siswa sekolah dasar itu terjadi karena di suatu tempat rumah tersebut terdiri dari lebih dari 1 kepala keluarga, mengingat di Bali, khususnya pedesaan lahan rumah mereka tergolong luas yang disebut dengan karang. Karang tersebut terdiri dari lebih dari 1 kepala keluarga dengan bangunan yang berbeda. Namun rata-rata dalam pengabdian ini 1 tutor/guru pendamping mendampingi 1 orang siswa dalam pembelajaran daring dan orang tuanya dalam hal pelaksanaan pembelajaran daring baik dari aplikasi, tatacara dan sebagainya.

$\begin{array}{lll} & \text { Pada masa pandemik covid-19 ini } \\ \text { banyak } & \text { keterbatasan } & \text { diantaranya }\end{array}$ permasalahan bahan ajar. Ada beberapa siswa yang tidak mempunyai bahan pembelajaran sehingga sumber belajar menjadi kurang, hal ini ditakutkan akan menurunnya prestasi dan kualitas belajar siswa. Melihat sebelumnya, ada beberapa orang tua siswa yang mempunyai alat komunikasi namun tidak support untuk pelaksanaan pembelajaran daring di rumah pada masa pandemik covid-19. Mengatasi hal ini, TIM pengabdian secara sukarela membantu untuk mengatasi permasalahan tersebut dengan meminjamkan gadget mereka, agar dapat mengakses pembelajaran daring yang sudah disiapkan oleh guru mereka sebelumnya.

Gadget dianggap sebagai suatu perangkat elektronik kecil yang memiliki fungsi khusus pada setiap perangkatnya yang mempunyai unsur terbarukan dan praktis (Rosiyanti \& Muthmainnah, 2018). Pandangan gadget ini lebih mengarah kepada perangkat keras yang memiliki software pembelajaran, seperti misalnya laptop, handphone, tablet dan sebagainya yang memiliki akses internet.

Pada pelaksanaan kegiatan itu, tampak juga ada beberapa orang tua siswa yang sudah memiliki gadget yang support terhadap pembelajaran daring, namun belum bisa menggunakan gadget untuk keperluan pembelajaran daring, mengingat banyak aplikasi-aplikasi yang belum pernah mereka gunakan, seperti misalnya whatshapp, google classroom, zoom, google form, google meeting, edmodo dan aplikasi pendukung lainnya. Untuk itu TIM pengabdian membantu menjelaskan dan mendampingi dalam menggunakan dan pemanfaatan aplikasi tersebut.
Pendampingan penggunaan aplikasi untuk orang tua siswa dan siswa itu sendiri yang terbilang sangat sederhana tersebut sudah mendapatkan solusi bagi mereka, sehingga pemanfaatan gadget untuk pembelajaran daring ini sudah teratasi, dengan teratasinya penggunaan gadget dalam pembelajaran daring ini, maka siswa dapat belajar dengan nyaman tanpa adanya hambatan mengani penggunaan aplikasi yang sangat menghambat pembelajaran, pengerjaan tugas, evaluasi (pemberian soal evaluasi oleh guru secara daring) dan feedback dari guru untuk mereka.

Seperti yang temukan oleh (Rosiyanti \& Muthmainnah, 2018) penggunaan gadget dalam pembelajaran memberikan pengaruh yang signifikan terhadap peningkatan hasil belajar siswa. Melihat hasil penelitian tersebut sangatlah penting gadget dalam menunjang pembelajaran daring ini sebagai sumber belajar, pelaksanaan pembelajaran, evaluasi pembelajaran secara daring dan digital akan sangat menarik minat siswa untuk belajar.

Gadget merupakan salah satu media pembelajaran terkini dan inovatif. Karena Media adalah segala sesuatu yang dapat menyalurkan informasi dari guru kepada siswa sehingga dapat merangsang pikiran, perasaan, perhatian dan minat siswa dalam kegiatan pembelajaran (Rahma, 2019). (Falahudin, 2004) Juga menyatakan bahwa Pemanfaatan media seharusnya merupakan bagian yang harus mendapat perhatian pembelajar dalam setiap kegiatan pembelajaran. Sehinga kurang tersedianya fasilitas dan media pembelajaran di rumah sangat menghambat dalam perolehan mengetahuan, ini sangat menghambat proses pembelajaran di rumah selama masa pandemik covid-19.

Seperti yang ditemukan oleh (World Health Organization. et al., 2020) bahwa kendala dalam pembelajaran daring guru sekolah dasar antara lain adalah aplikasi pembelajaran, jaringan internet dan gawai, pengelolaan pembelajaran, penilaian, dan pengawasan. Dengan menghadirkan TIM pengabdian ke lapangan melalui dor to dor, masalah khsususnya mengenai aplikasi pembelajaran dan jaringan internet sudah dapat diatasi, sehingga guru di sekolah dasar tersebut merasa terbantukan dan sangat mempermudah dalam pengawasan.

Media pembelajaran sangat penting dalam menunjang pembelajaran, seperti yang ditemukan oleh (Supriyono, 2018) penggunaan media dalam proses pembelajaran dapat pula memberikan pengalaman bermakna bagi para peserta didik.

Melalui pengabdian kepada masyarakat ini, maka segala permasalahan 
yang ditemukan di Kabupaten Bangli bagian utara sudah dapat teratasi, dengan teratasinya permasalahan pembelajaran daring selama masa pandemik covid-19 ini, niscaya memberikan pengaruh yang optimal terhadap peningkatan prestasi belajar siswa selamat belajar di rumah.

\section{SIMPULAN DAN SARAN}

Berdasarkan hasil dan pembahasan, simpulan pengabdian ini adalah sebagai berikut: Pertama, Kegiatan ini, sangat memberikan manfaat bagi orang tua siswa, anak-anak, guru dan masyarakat sekitar dalam belajar di rumah selama masa pandemic Covid19 dengan tetap memperhatikan protocol kesehatan. Kedua, hambatan yang dialami oleh anak-anak usia sekolah dasar dalam belajar di rumah sudah dapat diatasi. Ketiga, Siswa kelas rendah sudah dibantu dalam mencarikan sumber-sumber bahan ajar, Keempat, fasilitas pembelajaran sudah dibantu untuk meminjamkan sementara tentunya didampingi, mengingat masih kurangnya pemahaman mereka dalam menggnakan gadget. Kelima, orang tua siswa dalam mengajar anak-anak meraka di rumah terbantu dengan mendapatkan pendampingan belajar dari TIM pengabdian di rumah selama masa pandemic Covid-19. Keenam, para orang tua ada yang tidak memiliki gadget yang support terhadap pembelajaran daring, sudah terbantukan oleh peminjaman gadget di atas dan orang tua siswa juga di bantu dalam menggunakan aplikasi pada gadget untuk belajar di rumah

Adapun saran yang dapat diajukan adalah hendaknya perlu adanya pendampingan belajar untuk anak-anak usia sekolah dasar dalam belajar di rumah, mengingat kondisi geografis bangli wilayah utara sangat terpencil sebagai upaya mengatasi kesulitan belajar di rumah pada masa pandemi Covid-19.

\section{DAFTAR RUJUKAN}

Falahudin, I. (2004). Pemanfaatan Media dalam Pembelajaran Tari. Jurnal Lingkar Widyaiswara, 1(4), 104-117.

Kompas.com. (2020). Diumumkan awal Maret, Ahli: Virus Corona Masuk Indonesia dari Januari. Diterima pada 11 Mei 2020 melalui.

Https://Www.Kompas.Com/Sains/Read/2 020/05/11/130600623/Diumumkan-AwalMaret-Ahli--Virus-Corona-MasukIndonesia-Dari-Januari., 1. https://www.kompas.com/sains/read/2020 /05/11/130600623/diumumkan-awalmaret-ahli--virus-corona-masukindonesia-dari-januari

Rahma, F. I. (2019). (kajian terhadap Langkah- langkah Pemilihan Media dan Implementasinya dalam Pembelajaran bagi Anak Sekolah Dasar). Jurnal Studi Islam.

Rosiyanti, H., \& Muthmainnah, R. N. (2018). PENGGUNAAN GADGET SEBAGAI SUMBER BELAJAR MEMPENGARUHI HASIL BELAJAR PADA MATA KULIAH MATEMATIKA DASAR. FIBONACCI: Jurnal Pendidikan Matematika Dan Matematika.

https://doi.org/10.24853/fbc.4.1.25-36

Supriyono, S. (2018). Pentingnya Media Pembelajaran Untuk Meningkatkan Minat Belajar Siswa Sd. Edustream: Jurnal Pendidikan Dasar.

Trianto. (2010). Mendesain Model Pembelajaran Inovatif-Progresif. Jakarta : Kencana Prenada Media.

WHO. (2020). WHO COVID-2019 Situational Report $20 \quad$ May 2020. Https://Www.Who.Int/Docs/Default-

Source/Coronaviruse/Situation-

Reports/20200520-Covid-19-Sitrep121.Pdf?Sfvrsn=c4be2ec6_2, 8(1), 3-8.

World Health Organization., World Bank., RuizIbán, M. A., Seijas, R., Sallent, A., Ares, O., Marín-Peña, O., Muriel, A., Cuéllar, R., Mobasheri, A., Batt, M., Quintana, J. M., Escobar, A., Arostegui, I., Bilbao, A., Azkarate, J., Goenaga, J. I., Arenaza, J. C., Murphy, L. B., ... Cardiel, M. H. (2020). KENDALA PEMBELAJARAN DARING GURU SEKOLAH DASAR DI KABUPATEN BANJARNEGARA. Osteoarthritis and Cartilage. 